\title{
HUKUM NON MUSLIM SEBAGAI PEMIMPIN MUSLIMIN DITINJAU DARI PERSPEKTIF TAFSIR IBNU KATSIR
}

\author{
Muqtashidin Fahrusy Syakirin Al Hazmi \\ Institut AgamaIslam Negeri Metro \\ E-Mail : Memohon_ampunan@yahoo.com
}

\begin{abstract}
Abstrak
Ummat Islam telah lama hidup berdampingan dengan non muslim, mereka saling melakukan transaksi jual-beli, hutang-piutang, dan kegiatan-kegiatan mu'amalah lainnya. Akan tetapi non muslim menjadi pemimpin bagi ummat Islam mempunyai hukum tersendiri seperti yang sudah dijelaskan oleh Allah subhanahu wata'ala dalam firmanfirman-Nya di kitab suci al-Qur'an.Fenomena banyaknya pendapat terkait hukum non muslim menjadi pemimpin muslimin terkhusus di Indonesia mengharuskan ummat Islam untuk mengetahui dengan baik haqiqat hukum tersebut langsung dari kitab Suci mereka yaitu al-Qur'an berdasarkan pemahaman para 'ulama mereka terdahulu. Maka penulis meneliti mufasir yang terpercaya dan telah diakui oleh para 'ulama Islam, yaitu Ibnu Katsir dalam memahami ayat-ayat terkait hukum non muslim menjadi pemimpin muslimin. Tulisan ini merupakan penelitian library research atau studi keputakaan yang bersifat deskriptif kualitatif. Hasil penelitian menunjukkan bahwa hukum kepemimpinan non muslim terhadap ummat Islam dilarang dalam agama, bahkan Imam Ibnu katsir menyatakan orang yang mengangkat non muslim menjadi pemimpin bagi ummat Islam sebagai orang munafiq.
\end{abstract}

kata kunci : non muslim, pemimpin, ummat Islam,tafsir al-Qur'an

\section{A. Pendahuluan}

Islam adalah agama yang sempurna, dimana setiap sisi kehidupannya telah mempunyai rambu-rambu dan batasan-batasan yang boleh dan tidak boleh dilakukan oleh pemeluknya. Diantara rambu-rambu yang ada adalah berkaitan mengenai kepemimpinan.

Al-Qur'an surat al-Maidah ayat 51 yang disinggung oleh Ahok pada masa kampanyenya adalah bukti bahwa Islam sudah mempunyai rambu-rambu dalam kepemimpinan sehingga Ahok pun harus mengutip dan menyinggung firman Allah subhanahu wata'ala tersebut agar sukses dalam pemilu yang akan dilaluinya ini.

Sudah menjadi pengetahuan umum bahwa al-Qur'an itu tidak bisa dipahami sekehendak pribadi masing-masing, karena setiap orang pasti mempunyai kepentingan yang berbeda-beda, sehingga sangat memungkinkan kerancuan tafsir alQur'an jika al-Qur'an ditafsirkan oleh peribadi masing-masing orang.

Menafsirkan Al Qur'an semata-mata dengan akal dan opini tanpa landasan ilmu yang benar, hukumnya haram dan terlarang1. Hukum ini didasari oleh firman Allah subhanahu wata'ala :

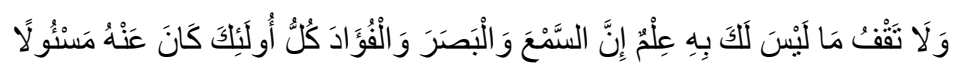


"Dan janganlah kamu mengikuti apa yang kamu tidak mempunyai pengetahuan tentangnya. Sesungguhnya pendengaran, penglihatan dan hati, semuanya itu akan diminta pertanggungan jawabnya" (QS. Al Isra: 36).

Dalam ayat tersebut, Allah subhanahu wata'ala dengan tegas memperingati ummat Islam untuk tidak mengikuti apasaja yang tidak ada ilmu di dalamnya. Dan Dari Ibnu Abbas radhiallahu'anhuma, Rasulullahshallallahu 'alaihi wasallam bersabda:

$$
\text { من قال في القر آن بغير علم فليتبوا مقعده من النار }
$$

"barangsiapa yang berkata tentang Al Qur'an tanpa ilmu maka siapkanlah tempat duduknya di neraka" (HR. At-Tirmidzi,no.2950)

Juga diriwayatkan dari Jundab bin Abdillah radhiallahu'anhu:

$$
\text { من قال في القرآن بر أيه فأصاب فقد أخطأ }
$$

“barang siapa siapa yang berkata tentang Al Qur'an sebatas dengan opininya, lalu kebetulan ia benar, maka ia tetap salah"(HR. At-Tirmidzi, no. 2952)

Oleh karena itu, generasi terbaik umat Islam yaitu para sahabat Nabi, para tabi' in, dan tabiut tabi'in, mereka tidak berani menafsirkan Al Qur'an jika mereka tidak tahu tafsirnya. Suatu ketika Sa'id bin Musayyib ditanya mengenai tafsir sebuah ayat, beliau mengatakan:

$$
\text { إنا لا نقول في القران شيئا }
$$

"kami tidak (berani) beropini sedikit pun mengenai tafsir Al Qur'an" (Diriwayatkan Imam Malik dalam kitab al-Muwatho ${ }^{2}$ Beliau katakan demikian karena tidak tahu mengenai tafsir ayat tersebut.

Dan diriwayatkan bahwa Abu Bakar Ash Shiddiq radhiallahu'anhu pernah ditanya

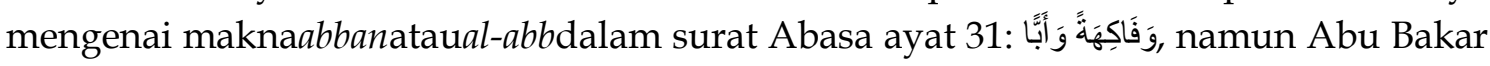
mengatakan:

$$
\text { أي سماء تظلني؟ و أب أرض تقلني؟ إذا قلت في كلام الله ما لا أعلم }
$$

"Langit mana yang akan menaungiku? Bumi mana yang akan menopangku? Jika aku berkata tentang kalamullah yang aku tidak ketahui (tafsirnya)"(Diriwayatkan Ibnu Abi Syaibah $)^{3}$

Ath Thabari mengatakan: "Kabar-kabar dari para salaf ini bukti kebenaran bahwa penafsiran ayat Al Qur'an tidak bisa diketahui ilmunya kecuali dengan penjelasan Rasulullah shallallahu'alaihi wasallam, atau dengan adanya dalil yang mendukungnya. Tidak boleh seorang pun berkata tentang tafsirnya hanya dengan opininya. Jika kebetulan perkataannya benar, maka ia tetap salah atas perbuatannya yang berani bicara mengenai tafsir dengan semata opini. Karena perkataannya yang benar tersebut bukanlah kebenaran yang benar-benar ia yakini kebenarannya, melainkan hanya kira-kira dan sangkaan saja. Dan orang yang berbicara masalah agama dengan modal sangkaan, sama saja ia berbicara tentang Allah tanpa ilmu. Dan Allah telah melarang hal itu terhadap hamba-Nya. Allah berfirman:

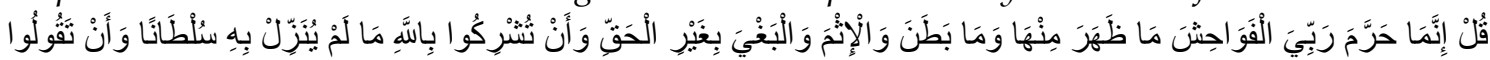

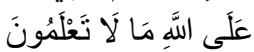

"Katakanlah: "Tuhanku hanya mengharamkan perbuatan yang keji, baik yang nampak ataupun yang tersembunyi, dan perbuatan dosa, melanggar hak manusia tanpa alasan yang benar, (mengharamkan) mempersekutukan Allah dengan sesuatu yang Allah tidak menurunkan hujjah untuk itu dan (mengharamkan) mengada-adakan terhadap Allah apa yang tidak kamu ketahui"(QS. Al A'raf: 33)"4

\footnotetext{
2 Manna'al Qothon, Mabahits, ... hlm. 343

3 ibid

${ }_{4}^{4}$ ibid
} 
Dewasa ini banyak sekali masyarakat yang mencoba menafsirkan ayat-ayat terkait kepemimpinan non muslim ditengah ummat Islam, berangkat dari surat al-Maidah ayat 51 yang kemudian menjalar kepada ayat-ayat lainnya, seperti surat al-Imron ayat 28 , surat al-Maidah ayat 57, surat at-taubah ayat 23 dan surat an-Nisa ayat 139 . Yang banyak dalam penafsiran mereka tidak merujuk atau kembali kepada pemahaman para pendahulu mereka, yaitu para sahabat, tabi'in dan tabi'ut tabi'in. Pada hakikatnya penafsiran ayat tersebut bukanlah hal yang baru, sudah banyak para pemikir Islam yang menyumbangkan waktu, tenaga, dan kesempatan yang dimilikinya untuk menjelaskan ayat-ayat tersebut kepada ummat, diantara mereka adalah Imam Ibnu Katsir rohimahullahu ta'ala.

Nama lengkap beliau adalah Imad ad-Din Abul Fida Ismail bin Amar bin Katsir bin Zara' al-Bushro al-Dimasqiy ${ }^{5}$ yang dikenal dengan sebutan Ibnu katsir, yang karya tafsirannya dituangkan dalam kitab Tafsir al-Qur'an al-'Adzim yang dikenal dengan Tafsir Ibnu Katsir. Kitab Tafsir Ibnu Katsir ini telah diakui oleh 'ulama Islam, sehingga ia termasuk dalam kitab yang terkenal di kalangan ummat muslim karena kitab ini termasuk kitab yang pertama keluar di agama Islam ini ${ }^{6}$, kitab Tafsir Ibnu Katsir juga termasuk kitab yang menggunakan metode Tafsir Riwayah wal diroyah (Tafsir dengan menggunakan kisah dan pembuktian $)^{7}$. sehingga ummat muslim terutama yang berada di Indonesia tidak salah dalam memahami ayat-ayat suci al-Qur'an dan dapat mengetahui dan mengamalkan hukum yang terkandung dalam ayat suci tersebut.

Pada garis besarya tafsir Ibnu Kasir ini merupakan kitab tafsir bil ma'sur yang terbaik, yang hal ini diakui oleh sebagian ulama. antara lain Imam Suyuti di dalam kitab Tazkiratul Huffaz dan Az-Zarqanidi dalam kitab Syarah Al-Mawahib. Keduanya mengatakan bahwa sesungguhnya tafsir Ibnu Kasir ini merupakan suatu karya tulis yangbelum pernah ada karya tulis yang semisal menandinginya. ${ }^{8}$

B. Kajian Teori

\section{Definisi Hukum}

Pergaulan hidup masyarakat dapat menjadi tertib dan teratur karena adanya tatanan dalam masyarakat. Tatanan masyarakat itu pada hakikatnya merupakan perumusan suatu pandangan mengenai perilaku atau sikap yang seyogyannya tidak dilakukan, yang dilarang dijalankan atau yang dianjurkan untuk dijalankan. Dengan adanya tatanan masyarakat maka dapat dicegah gangguan-gangguan kepentingan manusia dan akan dapat dihindarkan bentrokan antar kepentingan sehingga diharapkan kepentingan-kepentingan manusia dapat dilindungi. Tatanan masyarakat ada yang berbentuk tulisan ada yang tidak tertulis yang hidup dan berkembang berdasarkan keyakinan dalam masyarakat yang diteruskan dari satu generasi ke generasi berikutnya. Segala sesuatu yang dapat menciptakan ketertiban

\footnotetext{
${ }^{5}$ Muhammad Husein Adz-Dzahabi, at-Tafsir wal Mufassirin, jilid kedua, Mesir : Maktabah Wahbah, 1985, hlm. 242

${ }^{6}$ A.Rahman I.Doi, Penjelasan Lengkap Hukum-hukum Allah (Syari'ah), Jakarta : PT Raja Grafindo Persada, cet. Pertama, 2002, hlm.48

7 Ibid. hlm. 49

${ }^{8}$ Rudi, Pengantar Tafsir Ibnu Katsir, dinukil dari Ibnukatsironline.com, Agustus 2014
} 
dan keteraturan dalam masyarakat yang berupa aturan tingkah laku dapat dikatakan sebagai salah satu ciri hukum.

Merupakan kenyataan bahwa setiap saat hidup manusia dikuasai oleh aturan tingkah laku. Aturan tingkah laku berlaku sejak dalam kandungan sampai manusia lahir ke dunia dan meninggal dunia. Tatanan masyarakat yang memuat tingkah laku secara material dapat dikatakan sebagai hukum. Maka hubungan hukum yang terdapat dalam masyarakat tentulah tidak terhingga jumlahnya. Akibatnya hukum tidak terbatas pada suatu segi saja dan terdapat dimana-mana. ${ }^{9}$

Di dalam literatur hukum sudah ada beberapa definisi hukum dari para ahli yang dapat dipandang memadai rumusnya. Diantaranya adalah :

1) Hukum adalah keseluruhan daripada norma-norma yang secara mengikat hubungan yang berbelit-belit antara manusia dalam masyarakat. (Capitant) ${ }^{10}$

2) Hukum adalah himpunan peraturan-peraturan yang berisi perintahperintah dan larangan-larangan yang mengurus tata tertib suatu masyarakat dank arena itu harus ditaati oleh masyarakat tersebut. (C.Utrecht) $)^{11}$

3) Hukum adalah karya manusia berupa norma-norma yang berisikan petunjuk-petunjuk tingkah laku. Hukum merupakan cerminan dari kehendak manusia tentang bagaimana seharusnya masyarakat dibina dank e mana harus diarahkan. Oleh karena itu pertama-tama, hukum mengandung rekaman ide-ide yang dipilih oleh masyarakat tempat hukum diciptakan. Ide-ide tersebut berupa ide mengnai keadilan. (Satjipto Rahardjo) ${ }^{12}$

4) Hukum adalah peraturan-peraturan bersifat memaksa yang dibuat oleh badan-badan resmi yang wajib, yang menentukan tingkah laku manusia dalam lingkungan masyarakat, pelarnggaran terhadap peraturanperaturan tadi berakibat diambilnya tindakan hukuman. (J.C.T.. Simorangkir dan Woerjono Sastropranoto) ${ }^{13}$

Dari beberapa definisi yang berkaitan dengan hukum diatas, tampaklah bahwa hukum meliputi, kehidupan manusia dalam pergaulan masyarakat yang menyangkut hidup dan kehidupan manusia agar lebih teratur, serta merupakan pedoman atau patokan sikap tindakan atau perilaku yang pantas dalam pergaulan hidup diantara manusia.

2. Definsi Muslim

Muslim secara etimologi merupakan bentuk fa'il (subyek / pelaku) darikata kerja aslama-yuslimu-Islaman. Karena hanya sebagai subyek dariperbuatan Islam, maka pengertiannya tergantung pada pengertian Islam itu sendiri. ${ }^{14}$

Apabila kata Islam secara bahasa berarti damai, menyerah, patuh, selamat, sejahtera dan sebagainya. Muslim pun secara bahasa berarti orangyang damai,

\footnotetext{
${ }^{9}$ Chainur Arrasjid, Dasar-dasar Ilmu Hukum, Jakarta : Sinar Grafika, 2001 cet kedua, hlm.20

${ }^{10}$ Sudarsono, Pengantar Ilmu Hukum, Jakarta : PT Rineka Cipta, cet kelima, 2007, hlm.43

${ }^{11}$ Ibid

${ }^{12}$ Chainur Arrasjid, Dasar-dasar Ilmu Hukum, ..., hlm.21

13 ibid, hlm.22

${ }^{14}$ IAIN Syarif Hidayatullah, Ensiklopedi Islam Indonesia, Jakarta : Djambani, 1992, hlm. 701
} 
orang yang menyerah, orang yang patuh, orang yang selamat,orang yang sejahtera dan sebagainya.

Dalam istilah, Islam biasanya dirumuskan dalam dua arti, arti luas dansempit. Dalam arti luas, Islam adalah agama wahyu yang diturunkan kepadamanusia melalui seluruh nabi, sejak Adam sampai Muhammad. Sedangkandalam arti sempit, Islam adalah agama yang diturunkan untuk seluruh umatmanusia sampai hari kiamat melalui Nabi Muhammadsalallahu 'alahi wasalam.

Dengan demikian, pengertian muslim secara bahasa mempunyai artiluas dan sempit. Dalam arti luas, muslim adalah orang yang memeluk agama yang diturunkan kepada seluruh nabi. Dan dalam arti sempit, muslimadalah orang yang memeluk agama yang diturunkan kepada NabiMuhammadsalallahu 'alahi wasalam. 15

3. Definisi Non Muslim

Pengertian non muslim dapat dilihat dari pengertian muslim denganmendapat kata imbuhan non yang berarti tidak atau bukan. Maka non muslimberarti orang yang tidak atau bukan beragama Islam. ${ }^{16}$ Pengertian nonmuslim mempunyai makna bahwa seluruh pemeluk agama selain agamaIslam. Oleh karena Islam yang di bawa Nabi Muhammadsalallahu 'alahi wasalam sebagaipenyempurna agama yang di bawa nabi dan rasul sebelumnya, maka agamaIslam yang di bawa Nabi Muhammad salallahu 'alahi wasalammerupakan agama Islam terakhir.Dengan demikian, pengertian non muslim adalah pemeluk selain agama Islamyang di bawa oleh Nabi Muhammadsalallahu 'alahi wasalam.

Dalam agama Islam, tidak terdapat ajaran yang memaksakan seorangmanusia menjadi muslim. Hal ini sesuai dengan firman Allah dalam surat al-Baqoroh ayat 256 :

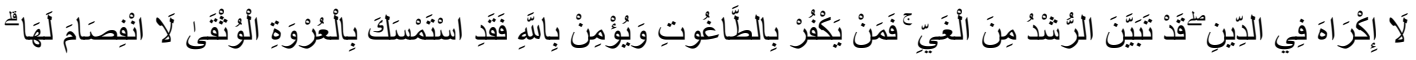

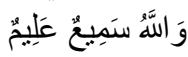

"Tidak ada paksaan untuk (memasuki) agama (Islam); sesungguhnya telah jelas jalan yang benar daripada jalan yang sesat. Karena itu barangsiapa yang ingkar kepada Thaghut dan beriman kepada Allah, maka sesungguhnya ia telah berpegang kepada buhul tali yang amat kuat yang tidak akan putus. Dan Allah Maha Mendengar lagi Maha Mengetahui".(QS. Al-Baqoroh : 256)

Dari keterangan tersebut, jelas bahwa yang dimaksud dengan nonmuslim adalah selain penganut agama Islam. Yang termasuk didalamnyaadalah penganut agama-agama di luar Islam, di Indonesia misalnya penganutagama Kristen, Katholik, Hindu, Buddha dan lain sebagainya.

Kelompok non muslim dapat dibedakan menjadi beberapa kelompok,Abdullah Nashih 'Ulwan membaginya menjadi empat kelompok, yaitu :kelompok ahli kitab, kelompok atheis dan murtad, kelompok paganis danmusyrikin, kelompok orangorang munafik. ${ }^{17}$

a. Kelompok Ahli Kitab

${ }^{15} \mathrm{Ibid}$

${ }_{16}$ Pusat Pembinaan dan Pengembangan Bahasa, Kamus Besar Bahasa Indonesia, Jakarta : Balai Pustaka, 1994, hlm.692

${ }_{17}$ Abdullah Nasih Ulwah, Konsep Islam Terhadap Non Muslim, Terj. Kathur Suhardi, Jakarta : Pustaka alKautsar, 1990, hlm.32 
Yang dimaksud dengan kelompok ahli kitab adalah orang-orang yang beragama berdasarkan salah satu kitab samawi dan mengikuti salahseorang nabi. Ahli kitab merupakan sebutan bagi komunitas yangmempercayai dan berpegang teguh kepada agama yang memiliki kitab suciyang berasal dari Tuhan selain Al Qur'an.18 Orang yang tetap berpegangteguh pada agama yang di bawa nabinya sebelum kenabian Muhammadsalallahu 'alahi wasalamatau sesudah kedatangan beliau tapi dakwah Islam belum sampaikepadanya, maka dia adalah orang yang mukmin. Sedangkan orang yangtetap pada agamanya, padahal ia tahu kerasulan Muhammad salallahu 'alahi wasalam dan dakwahbeliau, maka ia termasuk kelompok orang-orang kafir.

Pada zaman sekarang ahli kitab dapat dipisahkan lagi dalam 2kelompok yaitu :

1) Kelompok Yahudi, yaitu mereka yang berpegang teguh kepada syariatNabi Musa yang menerima kitab Taurat.

2) Kelompok Nashara, yaitu mereka yang berpegang kepada syariat Nabilsa yang menerima kitab Injil.

b. Kelompok Atheis dan Murtad

Murtad artinya perbuatan orang muslim yang meninggalkan agamayang telah diridhai Allahsubhanahu wata'ala, lalu memeluk agama lain selain Islam, ataumeyakini suatu akidah dan ideology tertentu yang bertentangan dengantatanan Islam. Sedangkan atheis adalah pengingkaran terhadap dzat Illahi,menolak risalah samawi yang telah diturunkan Allah kepada Rasulrasul-Nya. Atau dengan pengertian lain bahwa atheis merupakan pengingkarantentang hal-hal ghaib yang dibawa dan disampaikan lewat para rasul. ${ }^{19}$

c. Kelompok Paganis dan Musyrikin

Yang dimaksud dengan paganis adalah orang-orang yang membuatsesembahan selain Allahsubhanahu wata'ala, atau mengambil Tuhan di samping Allahsubhanahu wata'ala, seperti batu, api, pohon. ${ }^{20}$.

d. Kelompok Orang-orang Munafik

Kemunafikan adalah suatu sikap pada diri seseorang yang mengakungakuIslam, tapi jauh di lubuk hatinya menyimpan bara kekufuran yang menyala dan tujuan-tujuan yang menjijikkan. ${ }^{21}$ Sifat-sifat yang terdapatdalam orang yang munafik antara lain adalah : perkataannya selalu bohongdan dusta, perbuatannya dipenuhi bahaya dan kerusakan, bodoh, selalumemakai topeng yang berganti-ganti sesuai dengan kondisi yangdihadapinya.

4. Definisi Tafsir al-Qur'an

Para pakar sepakat bahwa al-Qur'an adalah kitab hidayah bukan buku ilmu pengetahuan, namun dalam memahami ayat-ayat kauniyah khususnya, tidak hlm. 46

${ }^{18}$ Abdul Azis Dahlan, Ensiklopedi Hukum Islam, Jakarta : Ichtiar Baru Van Hoeve, 1996, jilid pertama,

\footnotetext{
${ }^{19}$ Abdullah Nasih Ulwah, Konsep Islam Terhadap, ..., hlm. 62

${ }^{20}$ Ibid, hlm. 55

${ }^{21} \mathrm{Ibid}, \mathrm{hlm} .94$
} 
mungkin dilakukan dengan membaca al-Qur'an yang bertujuan ta'abud (ketaatan).22

a. Tafsir

Tafsir adalah suatu cara untuk mamahami isi kadungan al-Qur'an. Kata tafsir diambil dari bahasa Arab التفسير yang berasal dari فسر(menerangkan). Akan tetapi untuk menghindari kesalah pahaman pengertian tentang tafsir:23

1) Tafsir Menurut Bahasa (Etemologi).

Para ulama berbeda pendapat dalam memberikan pengertian tafsir secara bahasa diantaranya adalah:

a) Dalam Kamus Al-Munjid disebutkan.

Tafsir adalah isim masdar yang berarti ta'wil, pengungkapan, penjelasan, keterangan, dan penyerahan. ${ }^{24}$

b) Menurut Imam As-Suyuti.

Tafsir mengikuti wazan tafil berasal dari al-Fasru artinya menerangkan dan menyingkap. ${ }^{25}$

c) Menurut Al-Zarkasyi.

Tafsir dari kata tafsirah yang berarti alat yang dipakai oleh para dokter untuk memeriksa orang sakit, yang berfungsi membuka dan menjelaskan, sehingga tafsir berarti penjelasan. ${ }^{26}$

Dari pengertian tafsir menurut bahasa di atas pada dasarnya sama, meskipun disampaikan dengan bahasa yang berbeda. Tafsir memiliki arti penjelasan atau keterangan terhadap maksud yang sukar difahami dari ayat-ayat al-Qur'an. Dengan demikian, menafsirkan al-Qur'an ialah menjelaskan atau menerangkan makna-makna yang sulit difahami dari ayat-ayat Al-Qur'an. ${ }^{27}$

2) Tafsir Menurut Istilah (Etimonologi)

Pengertian tafsir secara etimonologi, sangat banyak sekali karena sebagian ahli mufassir mencoba untuk menta'rifkan tafsir dalam berbagai definisi, diantaranya sebagai berikut:

a) Menurut Al-Zarkasyi

Tafsir adalah ilmu untuk mengetahui pemahaman kitab Allah subhanahu wata'alayang diturunkan kepada Nabi Muhammadsalallahu 'alahi wasalam. Untuk menjelaskan berbagai makna, hukum dan hikmah yang terkandung didalamnya. ${ }^{28}$

b) Menurut Abu Hayyan.

Tafsir adalah ilmu yang membahas tentang cara-cara memahami teks yang berkaitan dengan petunjuk dan hukum-hukumnya baik yang berbentuk mufrad (teks) maupun konteksnya (التركيبه) serta

${ }^{22}$ Lois Ma'luf, al-Munjid Fil Lugho Wal A'lam, Bairut : Darul Misriq, 1971, hlm. 583

${ }^{23}$ Muhammad Husain adz-Dzahabi, Tafsir Wal ..., hlm.13

${ }^{24}$ Lois Ma'luf, al-Munjid Fil Lugho, ..., hlm.583

${ }^{25}$ Jalaluddin as-Suyuti, al-Itqon Fi Ulumil Qur'an, Bairut : Darul Fikr, 1979, juz kedua, hlm. 173

${ }^{26}$ Muhammad bin 'Abdillah Az-Zarkasyi, al-Burhan Fil 'Ulumil Qur'an, Mesir : Isa al-Babil Halabi, 1972, jilid kedua, hlm. 147

${ }^{27}$ Nasrudin Baidan, Wawasan Baru Ilmu Tafsir, Yogyakarta : Pustaka Pelajar, 2005, hlm. 67

${ }^{28}$ Ibid, hlm. 13 
makna yang dikandung oleh ayat-ayat tersebut secara kontekstual ataupun tekstual. ${ }^{29}$

Berdasarkan pengertian tersebut dapat dipahami bahwa tafsir adalah hasil usaha manusia atau ilmu yang memuat pembahasan mengenai penjelasan terhadap makna ayat-ayat al-Qur'an. Pemahaman tersebut bertujuan untuk penjelasan, memahami ayatayat yang belum jelas maksudnya menjadi jelas, yang samar menjadi terang dan yang sulit dipahami menjadi mudah, sehingga al-Qur'an yang fungsi utamanya adalah sebagai pedoman hidup (hidayah) bagi manusia, dapat dipahami, dihayati dan diamalkan sebagai mestinya. ${ }^{30}$

5. Biografi Ibnu Katsir

a. Kelahiran dan Wafatnya

Nama lengkap Ibnu Katsir adalah Imad ad-Din Abu al-Fida Ismaillbn Amar Ibn Katsir Ibn Zara' al-Bushra al-Dimasiqy.Beliau lahir di DesaMijdal dalam wilayah Bushra (Basrah) pada tahun 705 H. ${ }^{31}$

Ibn Katsir adalah anak dari Shihab ad-Din Abu Hafsh Amar IbnKatsir Ibn Dhaw Ibn Zara' al- Quraisyi, yang merupakan seorang ulamaterkemuka pada masanya.Ayahnya bermazhab Syafi'i dan pernahmendalami mazhab Hanafi. ${ }^{32 M e n g i n j a k ~ m a s a ~ k a n a k-~ k a n a k, ~ a y a h n y a ~ s u d a h m e n i n g g a l ~}$ dunia.Kemudian Ibnu Katsir tinggal bersama kakaknya (Kamalad-Din Abdul Wahhab) dari desanya ke Damaskus. Di kota inilah Ibn katsir tinggal hingga akhir hayatnya. ${ }^{33}$

Ibn Katsir mendapat gelar keilmuan dari para ulama sebagaikesaksian atas keahliannya dalam beberapa bidang ilmu yang digeluti,antara lain ia mendapat gelar seorang ahli sejarah, pakar tafsir, ahli fiqih,dan juga seorang yang ahli dalam bidang hadits. Sebagaimana yangdikatakan oleh Manna' al-Qatthan dalam Mabahits fil Ulum al-Qur'an,sebagai berikut:

"Ibn Katsir merupakan pakar figh yang dapat dipercaya, pakarhadits yang cerdas, sejarawan ulung, dan pakar tafsir yang paripuna". 34

Setelah menjalani kehidupan yang panjang, pada tanggal 26 Sya'ban 774 Hbertepatan dengan bulan Februari 1373 M pada hari kamis, Ibn Katsirmeninggal dunia.

b. Pendidikan

Pada usia 11 tahun Ibnu Katsir menyelesaikan hafalan alQur'an,dilanjutkanmemperdalam Ilmu Qiraat, dari studi Tafsir dan Ilmu Tafsirdari Syeikhul Islam Ibnu Taimiyah $\left(661-728\right.$ H). ${ }^{35}$

c. Guru-guru

Ibnu Katsir dibesarkan di kota Damaskus. Disana beliau banyakmenimba Ilmu dari para ulama di kota tersebut, salah satunya adalahBurhanuddin al-

\footnotetext{
${ }^{29}$ Abdul Djalal, Urgensi Tafsir Maudu'I Pada Masa Kini, Jakarta : Kalam Mulia, 1990, hlm.6

${ }^{30}$ Ibid

${ }^{31}$ Muhammad Husein Adz-Dzahabi, at-Tafsir, ..., hlm. 242

${ }^{32}$ Ibnu Katsir, al-Bidayah wan Nihayah,Bairut : Darul Fikr, jilid Empat Belas, hlm. 32

${ }^{33} \mathrm{Ibid}, \mathrm{hlm} .46$

${ }^{34}$ Manna al-Qotthon, Mabahits Fi ..., hlm.374

${ }^{35}$ Ibid. hlm.39
} 
Fazari (660-729 H) yang merupakan guru utama IbnuKatsir, seorang ulama terkemuka dan penganut mazhab Syafi'i. Kemudianyang menjadi gurunya adalah Kamal al-Din Ibnu Qadhi Syuhbah.

Kemudian dalam bidang Hadits, beliau belajar dari Ulama Hijaz danmendapat ijazah dari Alwani serta meriwayatkannya secara langsung dariHuffadz terkemuka di masanya, seperti Syeikh Najm al-Din ibn al'Asqalani dan Syhihab al-Din al-Hajjar yang lebih terkenal dengansebutan Ibnu al-Syahnah.

Dalam bidang Sejarah, peranan al-Hafizh al-Birzali (w. 730 H),sejarawan dari kota Syam, cukup besar. Dalam mengupas peristiwa-peristiwa Ibnu Katsir mendasarkan pada kitab Tarikh karya gurunyatersebut.Berkat al-Birzali dan Tarikh nya, Ibnu Katsir menjadi sejarawanbesar yang karyanya sering dijadikan rujukan utama dalam dalampenulisan sejarah Islam.

d. Karya-karya Tafsir

Ibnu Katsir menjadi ahli Tafsir ternama, ahli hadits, sejarawan serta ahli fiqh besar pada abad ke-8 H.Kitab beliau dalam bidang Tafsir yaitu Tafsir al-Qur'an al-'Adzim menjadikitab tafsir terbesar dan tershahih hingga saat ini, di samping kitab tafsirMuhammad bin Jarir at-Tahabari. Berikut ini adalah sebagian karyakaryaIbnu Katsir.

1) Tafsir al-Qur'an al-'Adzim.

2) Al-Bidayah wan Nihayah FitTarikh.

3) Al-Ijtihad fi Tolabil Jihad

4) As-Sunanul Hadi Liaqwami Sunan.

5) Al-Wadihun Nafis Fi Manaqibil Imam Muhammad bin Idris.

6) Jami' al-Masanid

7) Al-Kawakibud Darari dalam bidang sejarah, cuplikan pilihandari alBidayah wan Nihayah. ${ }^{36}$

e. Metode Penafsiran Ibn Katsir

Metode yang ditempuh oleh lbnu Kasir dalam kitab tafsirnya mempunyai ciri khas tersendiri. Pada mulanya dia mengetengahkan ayat, lalu menafsirkannya dengan ungkapan yang mudah dan ringkas. Jika memungkinkan baginya memperjelas ayat tersebut dengan ayat lain, maka dia mengetengahkannya, lalu melakukan perbandingan diantara kedua ayat yang bersangkutan sehingga maknanya jelas dan pengertian yang dimaksud menjadi gamblang.Dalam penjabarannya dia sangat menekankan tafsir cara ini yang mereka sebut dengan istilahtafsir al-Qur'an dengan al-Qur'an. Kitab tafsir Ibnu Kasir ini termasuktafsir yang paling banyak mengemukakan ayat-ayat yang salingberkaitan dalam satu makna di antara kitab-kitab tafsir lainnya yangdikenal.

Setelah selesai dari tafsir ayat dengan ayat, maka mulailah ia mengemukakan hadis-hadis yang berpredikat marfu' yang ada kaitannya dengan makna ayat, lalu ia menjelaskan hadits yang dapat dijadikan sebagai hujah dan hadits yang tidak dapat dipakai hujah diantara hadits-hadits yang dikemukakannya itu. Kemudian iamengiringinya dengan mengemukakan 
berbagai pendapat tentang ayattersebut dari para sahabat, para tabi'in, dan ulama Salaf yang sesudahmereka.

Di antara pendapat-pendapat tersebut dilakukan pentarjihanolehnya antara yang satu dengan yang lainnya, dan mendaifkansebagian riwayat serta menshahihkan sebagian yang lainnya; ia jugamenilai adil sebagian para perawi dan mendhaifkan sebagian yanglainnya. Hal ini tiadak lain berkat penguasaannya terhadap berbagai ilmuhadis dan keadaan para perawinya.Sering kita jumpai Ibnu Kasir menukil dari tafsir Ibnu Jarir, IbnuAbu Hatim, tafsir Ibnu Atiyyah, dan lain-lainnya dari ulama yangsebelumnya.

Termasuk di antara keistimewaan tafsir Ibnu Kasir ialah dia memperingatkan akan adanya kisah-kisah israiliyat yang mungkar didalam kitab tafsir ma'sur. la pun memperingatkan pembacanya agarbersikap waspada terhadap kisah seperti itu secara global, adakalanyapula menunjuknya dengan jelas dan menerangkan sebagian dari hal-halmungkar yang terkandung di dalamnya. ${ }^{37}$

C. Pembahasan

Dalam al-Qur'an terdapat beberapa ayat yang menjelaskan mengenai hukum boleh atau tidak bolehnya ummat Islam menjadikan non muslim sebagai pemimpin bagi mereka. Penulis akan coba mengedepankan setidaknya 5ayat sajayang membahas akan hal ini.

1. QS. Al-Imron : 28

Allah subhanahu wata'ala berfirman :

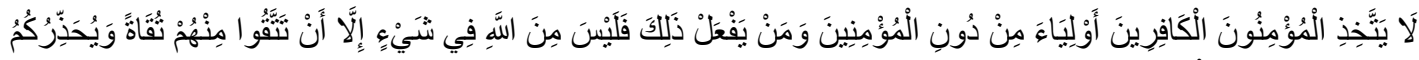

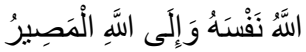

"Janganlah orang-orang mukmin mengambil orang-orang kafir menjadi auliya dengan meninggalkan orang-orang mukmin. Barang siapa berbuat demikian, niscaya lepaslah ia dari pertolongan Allah kecuali karena (siasat) memelihara diri dari sesuatu yang ditakuti dari mereka. Dan Allah memperingatkan kamu terhadap diri (siksa) Nya. Dan hanya kepada Allah kembali (mu)" (QS. Al Imran: 28)

Mengenai ayat ini, Imam Ibnu Katsir mengatakan :"Allah subhanahu wata'ala melarang hamba-hamba-Nya yang beriman untuk mengangkat orang-orang kafir sebagai wali dan pemimpin dengan kecintaan kepada mereka dan mengabaikan orang-orang yang beriman. Selanjutnya Allah subhanahu wata'ala mengancam perbuatan itu seraya berfirman: "Barang siapa yang berbuat demikian, niscaya lepaslah ia dari pertolongan Allah". Artinya, barangsiapa yang melanggar larangan Allah tersebut, maka ia benar-benar terlepas dari Allah subhanahu wata'ala."38

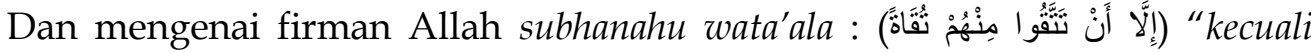
karena (siasat)memelihara diri dari suatu yang ditakuti dari mereka". Beliau berkata :"Maksudnya, kecuali bagi orang yang berada di suatu negeri dan pada waktu tertentu, merasa takut terhadap kejahatan orang-orang kafir, maka baginya diperbolehkan bersiasat kepada mereka secara lahirnya saja, bukan secara batin dan niatnya. Sebagaimana Imam al-

${ }^{37}$ Rudi,Pengantar Tafsir Ibnu Katsir, dinukil dari Ibnukatsironline.com, Agustus 2014

${ }_{38}$ Abdullah bin Muhammad, Tafsir Ibnu Katsir, Penj. M. Abdul Ghoffar, Bogor : Pustaka Imam asySyafi'I, 2003,juz 3, hlm. 32 
Bukhori meriwayatkan dari Abud Darda', ia berkata: "Sesungguhnya kami menampakkan wajah cerah kepada beberapa orang kafir, sedang hati kami melaknat mereka"". 39

Pendapat Abud Darda' yang diriwayatkan oleh Imam al-Bukhori diatas, itu jika kondisi ummat muslim lemah dan dipaksa untuk melakukan sesuatu hal yang bertentangan dengan aqidahnya, maka ia melakukan seperti itu, namun jika ummat muslim kuat, apalagi sebagai mayoritas ummat seperti di Indonesia dan tidak ada juga yang memaksa, maka sikap seperti itu dilarang. Sebagaimana firman Allah subhanahu wata'ala :

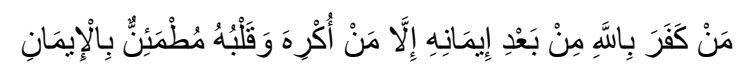
"Barangsiapa yang kafir kepada Allah sesudah Dia beriman (dia mendapat kemurkaan Allah), kecuali orang yang dipaksa kafir padahal hatinya tetap tenang dalam beriman (dia tidak berdosa)" (QS.An-Nahl:106)

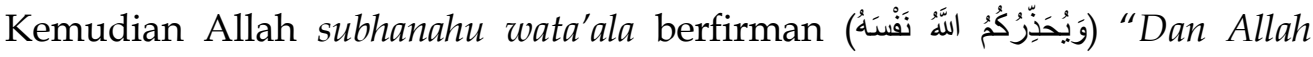
memperingatkan kamu terhadap diri (siksa)-Nya". Beliau berkata ;"dengan kata lain, Allah subhanahu wata'ala memperingatkan kalian akan siksa-nya di dalam penentangan terhadap-Nya dan adzab-Nya bagi orang-orang yang menjadikan musuh-Nya sebagai wali, dan memusuhi para wali-Nya. Selanjutnya Dia berfirman (وَإِلَى السَّهِ الََْصِيرُ) "Dan hanya kepada Allah kembali (mu)". Yaitu kepada-Nya tempat kembali untuk diberikan balasan bagi setiap orang atas amal yang diperbuatnya". ${ }^{40}$

Jelas dalam ayat diatas, bahwa Allah subhanahu wata'ala telah melarang ummat Islam untuk menjadikan non muslim sebagai wali dan pemimpin bagi mereka.

2. QS. Al-Maidah : 51

Pada saat ini, surat dan ayat ini lah yang sedang banyak dibicarakan oleh masyarakat di Indonesia, bahkan diantara mereka ada yang mencoba menjadi muffasir sehingga dapat menafsirkan firman Allah subhanahu wata'ala tersebut. Akan tetapi, bagaimanakah sebenarnya tafsiran 'ulama terdahulu mengenai firman Allah subhanahu wata'ala itu? Berikut ini akan Penulis jabarkan bagaimana Ibnu Katsir menafsirkannya. Allah subhanahu wata'ala berfirman :

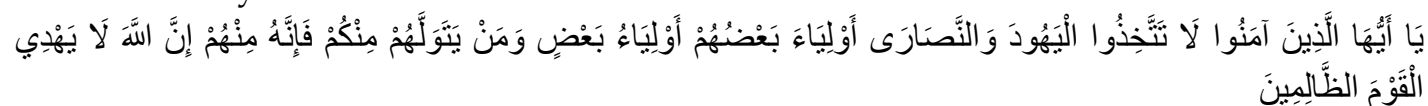

"Hai orang-orang yang beriman, janganlah kamu mengambil orang-orang Yahudi dan Nasrani menjadi auliya bagimu; sebahagian mereka adalah auliya bagi sebahagian yang lain. Barang siapa di antara kamu mengambil mereka menjadi auliya, maka sesungguhnya orang itu termasuk golongan mereka. Sesungguhnya Allah tidak memberi petunjuk kepada orang-orang yang lalim" (QS. Al Maidah: 51)

Dalam ayat yang fenomenal ini Ibnu Katsir berkata : "Allahsubhanahu wata'alamelarang hamba-hamba-Nya yang beriman mengangkat orang-orang yahudi dan nashroni sebagai pemimpin mereka, karena mereka itu adalah musuh-musuh Islam dan musuh para pemeluknya, semoga Allah membinasakan mereka. Selanjutnya Allah subhanahu wata'ala memberitahukan bahwa sebagian mereka adalah pemimpin bagi sebagian lainnya. Dan setelah itu Allah mengancam dan menjanjikan siksaan bagi orang

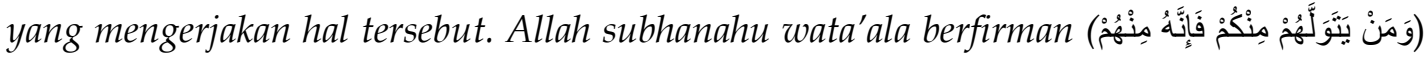
"Barangsiapa diantara kamu mengambil mereka sebagai pemimpin, maka sesugguhnya orang itu termasuk golongan mereka". Ibnu Abi Hatim mengatakan dari 'Iyad, "Bahwa

${ }^{39}$ Ibid

${ }^{40}$ Abdullah bin Muhammad, Tafsir Ibnu Katsir ...juz 3, hlm. 33 
'Umar pernah menyuruh Abu Musa al-Asy'ari untuk melaporkan kepadanya pemasukan dan pengeluaran (yang dicatat) pada selembar kulit yang telah disamak. Pada waktu itu, Abu Musa al-Asy'ari mempunyai seorang sekertaris beragama Nasrani. Kemudian sekertarisnya itu menghadap 'Umar untuk memberikan laporan, maka 'Umar sangat kagum seraya berujar, 'Ia benar-benar orang yang sangat teliti. Apakah engkau bisa membacakan untuk kami di masjid, satu surat yang baru kami terima dari syam.' Maka Abu Musa alAsy'ari mengatakan, bahwa ia tidak bisa. Maka 'Umar bertanya: 'Apakah ia junub?' Abu Musa menjawab: 'Tidak, tetapi ia seorang Nasrani.' Maka 'Umar pun menghardikku dan memukul pahaku, lalu berkata : 'Pecatlah orang itu.' Selanjutnya 'Umar membaca, (

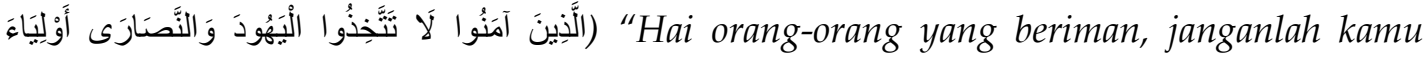
mengambil orang-orang Yahudi dan Nashrani menjadi pemimpin-pemimpin(mu)(sahabat karib).'"41

Begitulah pendapat Ibnu Katsir rohimahullah terhadap ayat ini, sehingga beliaupun mencantumkan sebuah riwayat agar dapat memperkuat pendapat beliau, bahwa ummat Islam tidak boleh menjadikan pemimpin non muslim atas diri mereka.

Ternyata ayat ini tidak berdiri sendiri, akan tetapi ayat ini masih berkaitan dengan ayat setelahnya, yang berbunyi :

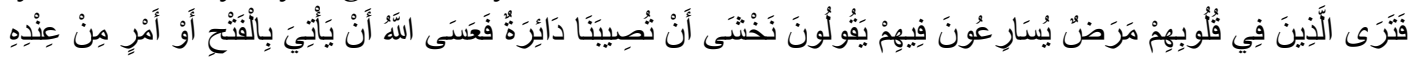

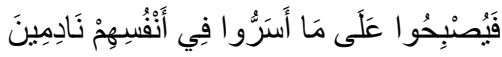

"Maka kamu akan melihat orang-orang yang ada penyakit dalam hatinya (orang-orang munafik) bersegera mendekati mereka (Yahudi dan Nasrani), seraya berkata: "Kami takut akan mendapat bencana". Mudah-mudahan Allah akan mendatangkan kemenangan (kepada Rasul-Nya), atau sesuatu keputusan dari sisi-Nya. Maka karena itu, mereka menjadi menyesal terhadap apa yang mereka rahasiakan dalam diri mereka." (QS. Al-Maidah :52)

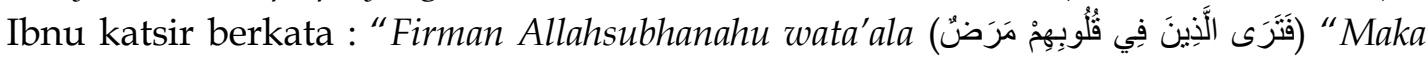
kamu akan melihat orang-orang yang ada penyakit di dalam hatinya". Yaitu berupa keraguan dan kemunafikan. Mereka dengan cepat mengangkat orang-orang Yahudi dan Nashrani sebagai pemimpin (kerabat), dan mencintai mereka, baik secara lahir maupun

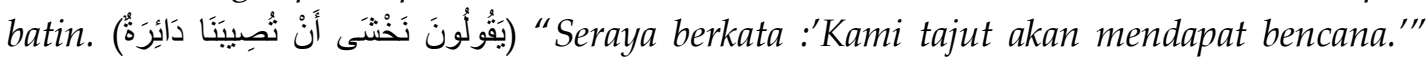
Mereka melakukan hal itu, yaitu dalam kecintaan dan loyalitas mereka adalah karena merasa takut akan terjadinya kemenangan kaum kafir atas kaum muslimin, jika hal ini terjadi, maka mereka mendapatkan perlindungan dari Yahudi dan Nashrani, maka hal itu bermanfaat bagi mereka. Mengenai hal tersebut Allah subhanahu wata'ala berfirman, (فَسَََى

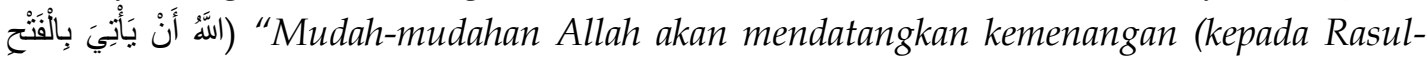
Nya)." As-Suddi mengatakan : "Yaitu Fathu Makkah (pembebasan kota Makkah)." Sedangkan 'ulama lainnya menafsirkan: "Yaitu ketetapan dan keputusan." (أَ أَمْر مِنْ عِنْدِ) "Atau suatu keputusan dari sisi-Nya." As-Suddi berkata : "Yaitu berupa pemberlakuan jizyah terhadap orang-orang Yahudi dan Nashrani." ('فَيُصنْبحُو "Maka karena itu, mereka." Yakni orang-orang munafik yang mengangkat orang-orang Yahudi dan Nashrani sebagai

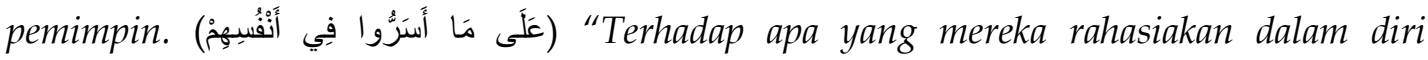
mereka." Yaitu atas pengangkatan orang-orang Yahudi dan Nashrani sebagai pemimpin. (نَادِيِنَ) "Menyesal." Yaitu atas tindakan mereka, dimana mereka tidak mendapatkan sesuatu pun dari mereka (orang-orang Yahudi dan Nashrani), bahkan mereka pun tidak memperoleh perlindungan, justru mereka malah mendapatkan keburukan dari mereka. Maka rahasia 
mereka pun terungkap dan Allah subhanahu wata'ala pun memeperlihatkan urusan mereka di dunia kepada orang-orang mukminin setelah sebelumnya urusan itu mereka rahasiakan, dimana tidak ada seorang pun yang mengetahui keadaan mereka sebenarnya. Tatkala rahasia mereka terbongkar, orang-orang mukminin pun melihat secara jelas jati diri mereka sesungguhnya. Maka mereka pun merasa heran, bagaimana mereka memperlihatkan bahwa orang-orang yang beriman, bahkan bersumpah untuk itu. Maka tampaklah dengan jelas kebohongan dan kemunafikan mereka itu. Oleh karena itu Allah subhanahu wata'ala berfirman:

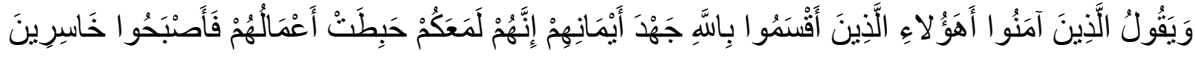

Dan orang-orang yang beriman akan mengatakan: "Inikah orang-orang yang bersumpah sungguh-sungguh dengan nama Allah, bahwasanya mereka benar-benar beserta kamu?" Rusak binasalah segala amal mereka, lalu mereka menjadi orang-orang yang merugi.."(QS. Al-Maidah : 53) ${ }^{42}$

Ibnu katsir rahimahullah sangat jelas pendapat beliau ketika menafsirkan QS. AlMaidah :51 diatas, bahwa orang yang menjadikan pemimpin non muslim bagi ummat muslim, mereka adalah orang-orang munafik yang menyembunyikan kemunafikan mereka diantara ummat Islam. Dan pendapat beliau ini dikuatkan lagi dengan 2 (dua) ayat setelahnya, karena ketiga ayat ini adalah satu kesatuan yang tidak bisa dipisahkan.

3. QS. Al-Maidah : 57

Pada hakikatnya, sebelum ayat ini $(54,55,56)$ masih berkaitan dengan firman Allah subhanahu wata'ala yang berada di QS. Al-Maidah : 51-53, hanya saja penulis ringkas agar lebih fokus kepada hukum non muslim menjadi pemimpin diantara ummat Islam. Allah subhanahu wata'alaberfirman :

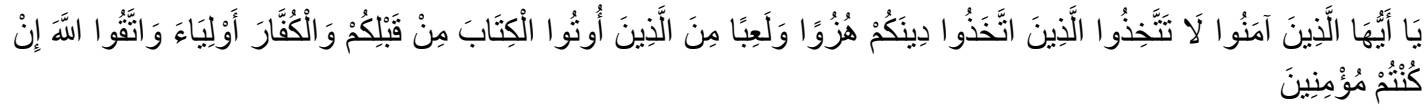

"Hai orang-orang yang beriman, janganlah kamu mengambil jadi pemimpin bagimu, orang-orang yang membuat agamamu jadi buah ejekan dan permainan, (yaitu) di antara orang-orang yang telah diberi Kitab sebelummu, dan orang-orang yang kafir (orang-orang musyrik). Dan bertakwalah kepada Allah jika kamu betul-betul orang-orang yang beriman" (QS. Al Maidah: 57)

Ibnu Katsir rahimahullah berkata : Yang demikian itu merupakan peringatan agar kaum muslimin tidak berlindung kepada musuh-musuh Islam, dan sekutunya dari kalangan Ahlul Kitab (Yahudi dan Nashrani) dan kaum musyrikin yang menjadikan syari'at Islam yang suci, muhkam (tegas), dan mencakup segala kebaikan dunia dan akhirat, sebagai bahan ejekan dan permainan menurut keyakinan dan pandangan mereka yang rusak, dan fikiran mereka yang beku. Sebagaimana yang diungkapkan oleh seorang penyair : 'Berapa banyak orang yang mencela ucapan yang benar, sebenarnya hal itu berpangkal dari pemahaman yang salah.'"43

Dalam ayat ini, Ibnu katsir ingin menegaskan bahwa mereka Ahlul Kitab dan orang-orang musyrik tidak akan dapat dipercaya selama-lamanya, karena mereka mempunyai keyakinan yang rusak dan salah, sehingga menjadikan firman Allah subhanahu wata'ala sebagai bahan ejekan dan permainan mereka. Kalau firman Allah subhanahu wata'ala saja berani mereka permainkan, lalu bagaiamana hal-hal

${ }^{42}$ Abdullah bin Muhammad, Tafsir Ibnu Katsir ... juz 6, hlm. 107-108

${ }^{43}$ Abdullah bin Muhammad, Tafsir Ibnu Katsir ... juz 6, hlm. 112 
yang berupa pendapat-pendapat sahabat Rasulullah salallahu 'alahi wasalam, 'ulama umat Islam dan terlebih 'ulama umat Islam saat ini, pasti lebih mereka remehkan lagi.

Ibnu Katsir melanjutkan tafsirnya dengan berkata :"Firman Allah subhanahu wata'ala (وَاتُقُو السَّ إِنْ كُنْنُمْ مُؤِْنِينَ) "Dan bertakwalah kepada Allah jika kamu betul-betul orang-orang yang beriman." Maksudnya, takutlah kepada Allah dari menjadikan musuh-musuh kalian dan agama kalian sebagai pelindung, jika kalian memang benar-benar orang-orang yang beriman kepada syari'at Allah subhanahu wata'ala yang mereka (musuh-musuh Islam)telah menjadikannya sebagai bahan ejekan dan permainan. ${ }^{44}$

4. QS. At-Taubah : 23

Allah subhanahu wata'ala berfirman :

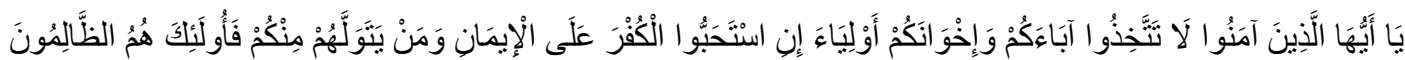
"Hai orang-orang yang beriman, janganlah kamu jadikan bapak-bapak dan saudara-saudaramu menjadi pemimpin-pemimpin bagimu, jika mereka lebih mengutamakan kekafiran atas keimanan dan siapa diantara kamu yang menjadikan mereka pemimpin-pemimpin bagimu, maka mereka itulah orangorang yang zhalim" (QS. At Taubah: 23)

Ibnu Katsir rahimahullah berkata :"Allah subhanahu wata'ala memerintahkan agar meninggalkan orang-orang kafir meskipun mereka itu adalah bapak atau anak kita. Allah subhanahu wata'ala juga melarang kita bersahabat dengan mereka jika mereka lebih memilih kekafiran daripada iman. Dalam hal ini, Allah subhanahu wata'ala juga memberikan peringatan, seperti firman-Nya :

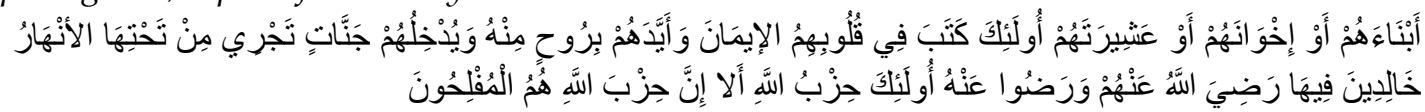

"Kamu tak akan mendapati kaum yang beriman pada Allah dan hari akhirat, saling berkasih-sayang dengan orang-orang yang menentang Allah dan Rasul-Nya, sekalipun orang-orang itu bapak-bapak, atau anak-anak atau saudara-saudara ataupun keluarga mereka. Meraka itulah orang-orang yang telah menanamkan keimanan dalam hati mereka dan menguatkan mereka dengan pertolongan yang datang daripada-Nya. Dan dimasukanNya mereka ke dalam surga yang mengalir di bawahnya sungai-sungai, mereka kekal di dalamnya. Allah ridha terhadap mereka, dan merekapun merasa puas terhadap (limpahan rahmat)-Nya. Mereka itulah golongan Allah. Ketahuilah, bahwa sesungguhnya hizbullah itu adalah golongan yang beruntung." (QS. Al-Mujadilah : 22)." ${ }^{45}$

Dalam ayat ini Ibnu Katsir mempertegas pendapatnya bahwa ummat Islam dilarang menjadikan non mulsim pemimpin bagi mereka, dengan mengatakan bahwa "Allah juga melarang kita bersahabat dengan mereka", kalau bersahabat saja beliau larang, apalagi sampai menjadikan mereka pemimpin. Bahkan diawal kata beliau adalah "Allah subhanahu wata'ala memerintahkan agar meninggalkan orang-orang kafir meskipun mereka itu adalah bapak atau anak kita." Dan pendapat beliau ini pun dikuatkan dengan firman Allah subhanahu wata'ala yang beliau nukil dari QS. AlMujadilah : 22.

5. QS. An-Nisa : 139

Allah subhanahu wata'ala berrfirman :

${ }^{44}$ Ibid

${ }^{45}$ Abdullah bin Muhammad, Tafsir Ibnu Katsir ... juz 10, hlm. 107-108 


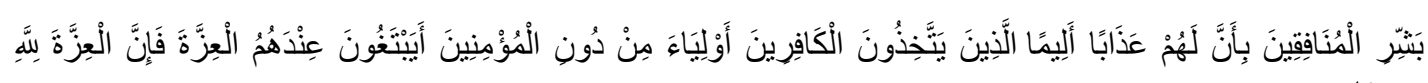
جَمِيعًا

"Kabarkanlah kepada orang-orang munafik bahwa mereka akan mendapat siksaan yang pedih (yaitu) orang-orang yang mengambil orang-orang kafir menjadi teman-teman penolong dengan meninggalkan orang-orang mukmin. Apakah mereka mencari kekuatan di sisi orang kafir itu? Maka sesungguhnya semua kekuatan kepunyaan Allah" (QS. An Nisa: 139)

Sebelum Imam Ibnu Katsir rahimahullah menafsirkan ayat ini, beliau terlebih dulu menafsirkan firman Allah subhanahu wata'ala yang ada di ayat sebelumnya (137 dan 138) bahwa tidak ada taubat bagi orang yang mati dalam keadaan kafir, kemudian

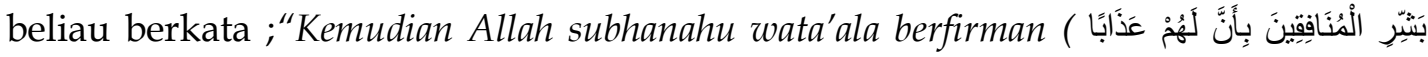
(ألَِيمًا (Kabarkanlah kepada orang-orang munafik bahwa mereka akan mendapatkan siksaan yang pedih." Yaitu, sesungguhnya orang-orang munafik termasuk bagian dari sifat ini. Karena, mereka itu beriman kemudian kufur, lalu dicaplah hati-hati mereka. Kemudian Allah menyifati mereka, bahwa mereka menjadikan orang-orang kafir menjadi pemimpinpemimpin mereka selain orang-orang mukmin, yang berarti bahwa mereka pada hakikatnya bersama orang-orang kafir, mereka loyal dan menyembunyikan kecintaan kepada orang kafir. Jika mereka datang kepada orang-orang kafir itu mereka berkata :'Sesungguhnya kami sependirian dengan kalian dan kami hanya berolok-olok terhadap orang-orang beriman dengan menampakkan keccocokan kami pada mereka.'"46

Dalam penjelasan ini, Imam Ibnu Katsir rahimahullah menerangkan bahwa mereka yang menjadikan pemimpin-pemimpin non muslim atas mereka adalah orangorang munafik yang menginginkan kebaikan dari pemimpin non muslim itu. Mereka beranggapan bahwa kepemimpinan non muslim itu bagus dan kami senang dengan kepemimpinan kalian, yang dengan kepemimpinan kalian ummat akan menjadi tenang, hidup damai, dan tertib. Padahal Islam lah yang mengajarkan perdamaian dan ketertiban dalam kehidupan, dan sesungguhnya pemimpin yang akan mendapatkan pertolongan Allah subhanahu wata'ala adalah pemimpin yang beriman. Seperti penjelasan Imam Ibnu Katsir berikutnya.

Beliau berkata :"Allah subhanahu wata'ala berfirman, mengingkari jalan yang mereka

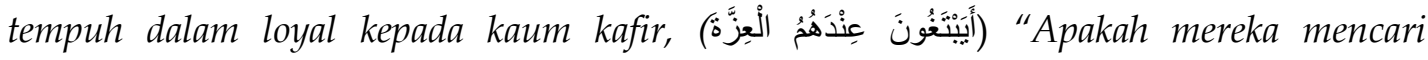
kemulian." Kemudaian Allah subhanahu wata'ala mengabarkan bahwa kemuliaan adalah milik-Nya semata, tidak ada sekutu bagi-Nya dan (kemuliaan itu pun diperoleh) bagi orang yang dijadikan kemuliaan itu untuknya, sebagaimana Allah subhanahu wata'ala berfirman,

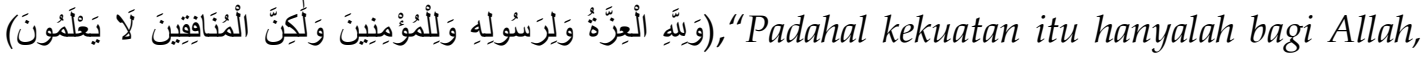
bagi Rasul-Nya dan bagi orang-orang mukmin, tetapi orang-orang munafik itu tiada mengetahui." (QS. Al-Munafiqun : 8). Maksud dari semua itu adalah dorongan untuk mencari 'izzah (kemuliaan) dari sisi Allah subhanahu wata'ala dan memfokuskan dalam pengabdian kepada-Nya, serta bergabung di dalam barisan hamba-hamba-Nya yang beriman, yang akan memperoleh pertolongan dalam kehidupan dunia dan pada hari kiamat. $^{47}$

${ }^{46}$ Abdullah bin Muhammad, Tafsir Ibnu Katsir ... juz 5, hlm. 430-431

${ }^{47}$ Abdullah bin Muhammad, Tafsir Ibnu Katsir ... juz 5, hlm. 431 
D. Kesimpulan

Islam membolehkan kaum muslimin bermuamalah dengan orang non muslim. Bahkan tradisi semacam ini ma' ruf dilakukan Rasulullah shallallahu 'alaihi wa sallam dan para sahabat. Mereka bermuamalah dengan orang yahudi di sekitar Madinah. Dan sebelumnya, kaum muslimin juga bermuamalah dengan masyarakat musyrikin Quraisy yang merupakan musuh besar mereka.

Akan tetapi, jika menjadikan non muslim menjadi pemimpin diantara ummat Islam, Imam Ibnu Katsir berpendapat tidak boleh, dan yang melakukan hal itu adalah orangorang munafiqun yang menyembunyikan kemunafikkannya dalam diri mereka, karena sesungguhnya Allah subhanahu wata'ala akan memberikan rahmat dan hidayah-Nya kepada ummat Islam bukan non muslim, dan pertolongan Allah subhanahu wata'ala hanya berlaku untuk ummat Islam.

Adapun ummat muslim yang berada di Negara mayoritas ummat non muslim, maka tidak ada jalan bagi mereka kecuali untuk memilih pemimpin yang paling ringan madhorotnya, meskipun itu adalah orang non muslim, tentu dengan hati yang berat dan tidak ridho akan kepemimpinan mereka, karena tidak ada calon pemimpin yang muslim, jika ada, maka bagi mereka untuk memilih calon pemimpin muslim tersebut.

Mengenai makna auliya yang menjadi perbincangan masyarakat, makna auliya itu bisa berarti teman akrab, pelindung, pemimpin, penolong maka ini bukanlah masalah dalam ilmu 'ulumul Qur'an, karena makna yang ada bukanlah makna yang berlawanan, sehingga makna tersebut saling melengkapi antara satu dengan yang lain. Sehingga ummat Islam tidak boleh menjadikan non muslim sebagai teman akrab, pemimpin, pelindung atau pun penolong mereka.

Wallahu 'alam 


\section{DAFTAR PUSTAKA}

Abdul Azis Dahlan, Ensiklopedi Hukum Islam, Jakarta : Ichtiar Baru Van Hoeve, 1996, jilid pertama

Abdul Djalal, Urgensi Tafsir Maudu'I Pada Masa Kini, Jakarta : Kalam Mulia, 1990

Abdullah bin Muhammad, Tafsir Ibnu Katsir, Penj. M. Abdul Ghoffar, Bogor : Pustaka Imam asy-Syafi'I, 2003

Abdullah Nasih Ulwah, Konsep Islam Terhadap Non Muslim, Terj. Kathur Suhardi, Jakarta : Pustaka al-Kautsar, 1990

A.Rahman I.Doi, Penjelasan Lengkap Hukum-hukum Allah (Syari'ah), Jakarta : PT Raja Grafindo Persada, cet. Pertama, 2002

Muhammad bin 'Abdillah az-Zarkasyi, al-Burhan Fil 'Ulumil Qur'an, Mesir : Isa al-Babil Halabi, 1972, jilid kedua

Chainur Arrasjid, Dasar-dasar Ilmu Hukum, Jakarta : Sinar Grafika, 2001 cet kedua

IAIN Syarif Hidayatullah, Ensiklopedi Islam Indonesia, Jakarta : Djambani, 1992

Ibnu Katsir, al-Bidayah wan Nihayah,Bairut : Darul Fikr, jilid Empat Belas

Jalaluddin as-Suyuti, al-Itqon Fi Ulumil Qur'an, Bairut : Darul Fikr, 1979, juz kedua

Lois Ma'luf, al-Munjid Fil Lugho Wal A'lam, Bairut : Darul Misriq, 1971

Manna'al Qothon, Mabahits fi'Ulumil Qur'an, Kairo-Mesir : Maktabah Wahbah, cet.7

Muhammad Husein Adz-Dzahabi, at-Tafsir wal Mufassirin, jilid kedua,Mesir : Maktabah Wahbah, 1985

Nasrudin Baidan, Wawasan Baru Ilmu Tafsir, Yogyakarta : Pustaka Pelajar, 2005

Pusat Pembinaan dan Pengembangan Bahasa, Kamus Besar Bahasa Indonesia, Jakarta : Balai Pustaka, 1994

Rudi, Pengantar Tafsir Ibnu Katsir, dinukil dari Ibnukatsironline.com,Agustus 2014

Sudarsono, Pengantar Ilmu Hukum, Jakarta : PT Rineka Cipta, cet kelima, 2007 